\title{
Analysis and Evaluation of Risks from Exposure to Noise in a Working Environment
}

\author{
Miriama Piňosová ${ }^{1, *}$, Miriam Andrejiová ${ }^{2}$, Miroslav Badida ${ }^{1}$, Marek Moravec ${ }^{1}$ \\ ${ }^{1}$ Technical University of Košice, Faculty of Mechanical Engineering, Institute of Design Machine and Process Engineering, Department of Process and \\ Environmental Engineering, Park Komenského 5, 04200 Košice, Slovakia \\ ${ }^{2}$ Technical University of Košice, Faculty of Mechanical Engineering, Institute of Automation, Robotics and Mechatronics, Department of Applied \\ Mathematics and Informatics, Letná 9, 04200 Košice, Slovakia
}

\begin{abstract}
This paper deals with a proposal of assessment of hearing impairment risk from the point of view of long-term exposure to noise in a selected plant in the Slovak Republic. Measurement and monitoring noise was carried out at two workshops of a mechanical engineering plant: in a "Cutting Center" and in a "Welding Center". A Norsonic sound analyser was used to measure noise exposure. Evaluation of the noise measurement results consisted of the comparison of the measured values with the required values, which are specified, in the relevant legislative regulation (Government Regulation No. 115/2006 Coll., technical standard (STN EN ISO 9612:2010) and Directive (Council Directive 2003/10/EC). The measured results show that the normalized levels of noise exposure, extended by the uncertainty of measurement $(\mathrm{U}= \pm 2,1 \mathrm{~dB})$ at the all workplaces, exceed the limits stipulated by the Slovak Government, all measured professions fall within the fourth category of work activities categorized according to the noise factor. Long-term exposure of the human organism to noise pollution can cause, in addition to hearing impairment, a wide range of other diseases. Very high levels of noise cause hearing impairment, lower levels affect the control system in our body. This paper presents the results of a study aimed at assessing the risks associated with acoustic noise in connection with exposure to noise at the workplace and with its possible negative effects (a risk event) to health and hearing of workers in the engineering industry.
\end{abstract}

Keywords: noise reduction strategy, acoustic risk, acoustic risk assessment matrix.

\section{Introduction}

Global studies highlight the fact that noise-induced hearing loss (NIHL) [1] is recording an alarming increase, particularly among young people [2] (Berger, 2002). Hearing loss is one of those things that will happen over time as a result of prolonged exposure to high noise levels. Once it happens, it is irreversible. In addition to hearing loss, prolonged exposure to high noise is known to cause fatigue, stress, anxiety, and depression, loss of concentration, reduced productivity, headaches and high blood pressure [3]. NIHL is one of the most common occupational diseases in countries of the European Union [4].

Damage to hearing from noise depends on a number of factors. These include the character of the noise, its frequency spectrum, its intensity and its duration. Other important aspects include the interval between the exposure and an individual's susceptibility [5].

Standard ISO 1999:1990 and of the National Institute for Occupational Safety and Health (NIOSH) [6] guidelines recommend the exposure limit of $85 \mathrm{~dB}(\mathrm{~A})$ equivalent 
sound pressure level $L_{\text {Aeq }}$ as the action level and the $3 \mathrm{~dB}$ exchange rate. That is, noise in excess of $85 \mathrm{~dB}(\mathrm{~A})$ for an eight-hour working day, i.e., a 40hour week, is considered to be hazardous and will cause hearing loss in $5 \%$ of the population. At $90 \mathrm{~dB}(\mathrm{~A})$ for an 8-hour workday, i.e., 40-hour week, $15 \%$ of the population will develop hearing loss due to cochlear damage [7]. For every 3-dB increase in exposure level, the allowable exposure duration is halved.

The equal energy hypothesis (EEH) based approach is generally considered appropriate for steady-state noises but not for impulsive noises [8]. Current noise guidelines recommend integrating impulsive and continuous noises according to the EEH [9]. For example, an exposure to a complex noise was observed to produce a much greater permanent threshold shift (PTS) and more extensive hair cell losses than an exposure to only an energy equivalent continuous or impulsive noise alone would have caused [10].

Due to harmonization of legislation of the European Union, a new approach to addressing safety and health at work has been introduced into our legal system as well. One of the basic principles of this approach is the policy that for achieving a good level of safety and health at work it is not sufficient only to comply with safety regulations, but it is necessary to implement active prevention into organization of work and into working conditions. It is necessary to take into consideration, beyond the scope of the rules, what can endanger people at work; it is necessary to assess the risks [11]. The most important European legal regulation concerning risk assessment is the Framework Directive 89/391/EEC [12]. Risk assessment is thus the beginning of the process of risk management. The European Agency for Safety and Health at Work (EU-OSHA) has prepared an EU-wide campaign focused on risk assessment. Its main purpose is to protect health and safety of employees. Risk assessment helps to minimize potential damage to employees, or to the environment, caused by work activity [13].

A large number of authors [14-16] have evaluated the quality of the work environment and assessed the negative impacts of physical factors in the working environment on the health of employees. Seňová [17] used a points-based assessment method to assess the risk of labouring professions in the quarries. Hnilica [18] focused his attention on the selection of methods that would enable a comprehensive assessment of the impact of risk factors on the working environment of humans. Similarly to Seňová, Hnilica also points out the possibility of using a points system for assessing risk factors in the work environment. As a further option, he chose the questionnaire method, which is a subjective assessment method. Hrušková [19] states that not enough attention is paid to problematic hearing damage from noise in the automotive industry. She warned of the necessity to perform pre-entry medical examinations before people begin work, with appropriate documentation of the exposure to risk factors in past work. Hnilica [20] tries to outline the possibility of using multi-criteria decision-making methods in the comprehensive assessment of the quality of the working environment in terms of the risk of work. The case study focused on four risk factors (noise, temperature, vibration and psychological load) that have the most significant impact on the health of operators in forestry operations. For the evaluation of these physical factors he chose Saaty's method (analytical hierarchical process). Kapustová [21], using mathematical statistical methods, developed an original mathematical model that enables the expression of the summary effect of negative environmental factors and to evaluate the complex load of the human body during the study period. Tolvanen [22] worked on the measurement of factors in the working environment and the assessment of working conditions at different workplaces. Repeated measurements were made at four locations within the production hall (near the conveyor belt, crusher, tank and barrier). In addition to noise levels, they detected dust concentrations in the air.

\section{Materials and Methods}

\subsection{Acoustic Risk Assessment in Practice}

Evaluation of working conditions can be considered as a process that results in expertise on the degree of health risk factors in the context of the surveyed work activities [23].

The basis for assessing working conditions with a possible relation to diseases and health damage is the assessment of potential risk factors, i.e. to assess their level of observation, analyzing workloads and working practices, measuring, and 
comparing results with prescriptions, limits and recommended values.

The risk of exposure to health and safety noise is due to the disturbing and harassing effects of noise in the work of employees requiring mental focus or auditory communication. The risk of employee hearing damage (changes) is generated after a long-term exposure to noise with a level above 80 $\mathrm{dB}$. When assessing the risk of exposure to noise, it is based on:

$\checkmark$ the nature of work activities of employees at individual workplaces (operations taking into account the demands of mental concentration or hearing communication at work,

$\checkmark$ noise levels, time and physical nature of the noise to which workers are subjected and the duration of noise during work changes,

$\checkmark$ measured (calculated) values of the normalized noise exposure level at a nominal time interval of 8 hours and (-peak sound pressure level, e.g. for individual employees or group of employees (profession),

$\checkmark$ assessment of compliance / non-conformity of the normalized noise exposure levels and (-peak sound pressure levels with limit and action values,

$\checkmark$ exceeding the length of exposure of the employee over his working hours,

$\checkmark$ availability and efficiency of personal hearing protectors due to the physical nature of the noise,

$\checkmark$ information obtained from health surveillance or the results of medical preventive inspections in relation to the work proved / proved no changes in the health status of employees, including information published in professional journals.

\subsection{Noise-Induced Hearing Loss}

The essences of damage to the auditory system, from the physiological point of view, are initially temporary and later permanent functional and morphological changes in the sensory and nerve cells of the organ of Corti in the inner ear. Epidemiological studies have shown that in 95\% of the exposed population no damage to the auditory apparatus occurs, not even during a lifetime exposure to noise in the environment and in leisure activities, at the 24-hour equivalent level up to $70 \mathrm{~dB}$. However, we cannot completely exclude the possibility that people more sensitive to noise, such as children or persons who are simultaneously exposed to vibrations, could not suffer from hearing damage under such conditions. After a long-term exposure of humans who are more sensitive to noise, permanent effects, such as hypertension, may develop [24].
Persistent noise increases, among others, the risk of fatigue and of stress, results in high blood pressure, sleep disorders, and also causes difficulties in concentration and communication [25]. The general conclusion of World Health Organization (WHO) is that these effects are associated precisely with long-term exposure (for 5-15 years) in the range of $65-70 \mathrm{~dB}$, and more [24]. Adverse health effects can be minimized also by reducing noise levels below $50 \mathrm{~dB}(\mathrm{~A})$ at workplaces, where work requiring high concentration is carried out and to $65 \mathrm{~dB}(\mathrm{~A})$ at workplaces, where work of a more routine nature is done, in which communication is part of the performed work [26].

\subsection{Minimum Health and Safety Requirements for the Protection of Workers from Risks Resulting from Exposure to Noise}

The scope of these regulations is to lay down minimum requirements for the protection of workers from risks to their health and safety arising or likely to arise from exposure to noise and in particular the risk to hearing. The requirements of these regulations shall apply to all those activities in which workers are, or are likely to be exposed to risks from noise as a result of their work. These regulations shall implement Directive 2003/10/EC [27] of the European Parliament and of the Council on the minimum health and safety requirements risks arising from physical agents (noise), as follows:)

$\checkmark$ Exposure limit values $>L_{E x, 8 h}=87 \mathrm{~dB}(A) a L_{C P k}=140 \mathrm{~dB}$.

$\checkmark$ Upper exposure action values $>L_{E x, 8 h}=85 \mathrm{~dB}(A) a L_{C P K}=137 \mathrm{~d} B$.

$\checkmark$ Lower exposure action values $>L_{E x, 8 h}=80 \mathrm{~dB}(A) a L_{C P K}=135 \mathrm{~dB}$.

Daily noise exposure level $L_{E x, 8 h}$ means the timeweighted average of the noise exposure levels for a nominal eight-hour working day as defined by international standard ISO 1999:2013 Acoustics - Estimation of noies-induced hearing loss [28] and ISO 9612:2009 Acoustics - Determination of occupational noise exposure - Engineering method [29].

\subsection{Risk Assessment Procedure for Noise-Induced Hearing Loss}

Risk assessment is used for making decisions about the severity of risks and whether a given risk can be accepted or measures for addressing it shall be taken. According to [30] the value of risk is expressed by the functional dependence of at least two parameters, i.e. 
Tab. 1: The degree of risk severity.

\begin{tabular}{|c|c|c|c|c|c|}
\hline \multirow{2}{*}{ Probability } & \multicolumn{5}{|c|}{ Severity of the impact of a risk event (Consequence, Impact) } \\
\hline & Negligible & Minor & Major & Significant & Severe \\
\hline Almost certain & $\begin{array}{c}5 \\
\text { Medium } \\
\end{array}$ & $\begin{array}{c}10 \\
\text { Medium }\end{array}$ & $\begin{array}{c}15 \\
\text { High } \\
\end{array}$ & $\begin{array}{c}20 \\
\text { Extreme } \\
\end{array}$ & $\begin{array}{c}25 \\
\text { Extreme }\end{array}$ \\
\hline Highly probable & $\begin{array}{c}4 \\
\text { Medium } \\
\end{array}$ & $\begin{array}{c}8 \\
\text { Medium }\end{array}$ & $\begin{array}{c}12 \\
\text { High } \\
\end{array}$ & $\begin{array}{c}16 \\
\text { High } \\
\end{array}$ & $\begin{array}{c}20 \\
\text { Extreme }\end{array}$ \\
\hline Probable & $\begin{array}{c}3 \\
\text { Low } \\
\end{array}$ & $\begin{array}{c}6 \\
\text { Medium } \\
\end{array}$ & $\begin{array}{c}9 \\
\text { Medium } \\
\end{array}$ & $\begin{array}{c}12 \\
\text { High } \\
\end{array}$ & $\begin{array}{c}15 \\
\text { Extreme }\end{array}$ \\
\hline Possible & $\begin{array}{c}2 \\
\text { Low }\end{array}$ & $\begin{array}{c}4 \\
\text { Medium } \\
\end{array}$ & $\begin{array}{c}6 \\
\text { Medium } \\
\end{array}$ & $\begin{array}{c}8 \\
\text { Medium } \\
\end{array}$ & $\begin{array}{c}10 \\
\text { High } \\
\end{array}$ \\
\hline Rare & $\begin{array}{c}1 \\
\text { Low }\end{array}$ & $\begin{array}{c}2 \\
\text { Low }\end{array}$ & $\begin{array}{c}3 \\
\text { Medium }\end{array}$ & $\begin{array}{c}4 \\
\text { Medium } \\
\end{array}$ & $\begin{array}{c}5 \\
\text { High }\end{array}$ \\
\hline Low & \multicolumn{5}{|c|}{ Very low, negligible level risk } \\
\hline Medium & \multicolumn{5}{|c|}{ Low level risk } \\
\hline High & \multicolumn{5}{|c|}{ High level risk } \\
\hline Extreme & \multicolumn{5}{|c|}{ Very high level risk } \\
\hline
\end{tabular}

$R=f(P, C)$

(1)

where $P$ represents the probability of occurrence of a risk event (hazard) and $C$ is the degree of severity in case of occurrence of a risk event, e.g. affecting human health, the environment and the like. It is often expressed by assigning to it a numeric value from 1 to 5 .

An important step in risk assessment is to determine the degree of significance of the risk and at the same time to determine the level of its acceptability. The degree of significance of a risk, in the simplest case, is the product of the scores assigned to the probability of occurrence of the risk and to the severity of risk impact (see Tab. 1), i.e.

$$
R=P \times C
$$

where $P$ is the probability of occurrence of a risk and $C$ is the severity of the risk.

For fulfilling the step of risk assessment, it is necessary to construct a risk matrix. In general, this matrix is formed by combining the two basic parameters $P$ and $C$. According to [31], when using a five-degree risk assessment, the numeric value of 15 is the expression of an unacceptable risk.

Risk assessment allows setting priorities, to select appropriate options and it is an effective means of preventing damage to health. The process of risk assessment is similar for all factors of the working environment and it also regards living environment [23].

\section{Results and Discusion}

This paper presents the results of a study focusing on the assessment of the acoustic risk associated with exposure to workplace noise and its possible adverse effects on the health and hearing of employees in the engineering industry.

The main sources of noise in the plant under consideration were the technological units of a "Cutting Center" and of a "Welding Center" and the work activities of the employees at the neighboring workplaces. The measurements were carried out so as to include at least one work cycle of the technological installations. At the workplaces in consideration, a two-shift operation was in place: the morning shift (from 6 AM to 2 PM) and the afternoon shift (from 2 PM to 10PM), with 30 minutes break for lunch. From the point of view of the relationship between the dose and the exposure to the risk factor, it was important to thoroughly process the job descriptions of the employees and the timeline of the duration of the daily exposure. The production lines in consideration were operated by operators who were working at the control consoles situated at the start and at the end of the production lines, respectively, but were also moving, for the purpose of their control, along the lines and in their immediate surroundings. The employees were not exposed to harmful factors at the start of the work shift, when work and the relevant technical documentation were prepared, the machines were set up and when planning of work was underway. A similar situation exists at the end of the work shift, when personal hygiene and cleaning of the workplaces is carried out, or when the employees leave their workplaces during personal breaks. The difference in duration of exposure to selected risk factors is also different from the point of view of 
Tab. 2: Working conditions at the monitored workshops.

\begin{tabular}{|c|c|c|}
\hline Workshop & Line operator "C.C." & Line operator "W.C." \\
\hline Average temperature & $21,8^{\circ} \mathrm{C}$ & $21,2^{\circ} \mathrm{C}$ \\
\hline Average relative air humidity & $34,9 \%$ & $33,1 \%$ \\
\hline Average velocity of airflow & $0,23 \mathrm{~m} / \mathrm{s}$ & $0,20 \mathrm{~m} / \mathrm{s}$ \\
\hline Normalized level of noise exposure for work category L $_{A E X, 8 h}$ & $L_{A E X, 8 h}=85,6 \mathrm{~dB}$ & $L_{A E X, 8 h}=80,9 \mathrm{~dB}$ \\
\hline Peak level of acoustic pressure of work $L_{c p k}$ & $L_{C p k}=108,2 \mathrm{~dB}$ & $\mathrm{~L}_{\mathrm{CPk}}=107,5 \mathrm{~dB}$ \\
\hline
\end{tabular}

the performed work profession.

Noise measurement and noise monitoring were carried out at two workshops of a mechanical engineering plant: in a "Cutting Center" and in a "Welding Center".

Conversion of noise exposure was performed for the professions: line operator at the "Cutting Center" and line operator at the "Welding Center". The workshop "Cutting Center" is located in a large one-room shop floor, where in addition to the cutting line there are also some other technological units. The "Cutting Center" is adjacent to the pressing shop. The workshop "Welding Center" is located in a large one-room shop floor adjacent to the production line "Drilling of the carrier". For the average values of microclimatic parameters of temperature and humidity of the working environment of both workshops see Tab. 2 .

The aim of the study was to examine the effect of noise exposure on human health in a selected group of employees. The objects of the research were employees who were exposed during work hours to unfavorable working environment in selected production facilities. According to the nature of the work activities of the employees in the respective production facilities, these workers fall into the category of works 4, i.e. we're performing work activities, for which noisy machines and tools are used, or which are implemented in a noisy environment with the limit value $L_{A E X, 8 h}=80 \mathrm{~dB}$.

The participants of the research were 20 male workers in the age group from 27 to 58 years. By using a prepared questionnaire, we have obtained from the employees participating in the research necessary information about their age, duration of employment (exposure time in years), job description, daily exposure time to negative factors, we have also asked them about their sensations and health symptoms, which may appear during their working hours, and which may have negative influence on their health. All the employees participating in the research have experienced some health problems, which in their opinion were related to their professional activity. For basic information about the employees: age, duration of exposure, see Tab. 3.

Tab. 3: Basic data of the employees.

\begin{tabular}{|c|c|c|}
\hline Characteristics & $\begin{array}{c}\text { Age } \\
\text { (years) }\end{array}$ & $\begin{array}{c}\text { Duration of exposure } \\
\text { (years) }\end{array}$ \\
\hline Arithmetic mean & 44,9 & 18,1 \\
\hline Standard deviation & 10,2 & 8,9 \\
\hline Max - Min & $58-27$ & $33-5$ \\
\hline
\end{tabular}

For assessment of the acoustic risk, we have used the relation $R=f(P, C)$, where $P=f\left(L_{A E X, 8 h}\right)$ is a function of the probability of exposure of a person to noise, which is determined by the normalized level of noise exposure $L_{A E X, 8 h}$. The probability represents the estimate of the possible occurrence of the risk of hearing impairment and of damage to health in persons exposed to noise.

The connections between the risk levels due to noise and stages of health complaints (probability) determined using the simple/flexible risk assessment method are presented in Table 4 and illustrated graphically in Figure 1.

Consequence $C$ assesses the level and the severity of damage to health and of hearing impairment of employees that may have occurred due to acoustic risk. It is a function of consequences of the acoustic loading and causes auditory (special effects, such as acute acoustic trauma, chronic acoustic trauma and hearing loss of various degrees), extra-auditory (non-specific disorders manifested by disorders of the nervous and of the cardiovascular systems and affecting the psyche) and other (difficulties with communication, accidents, etc.) damages to the human organism (see Table 5).

For evaluation of the acceptability of the level of a risk event, we used the risk matrix shown below (see Fig. 2).

The risk analysis shows that eight out of ten employees of the workshop "Cutting Center" work 
Tab. 4: Estimate of the probability of occurrence of a risk event.

\begin{tabular}{|c|c|c|l|}
\hline Probability & Value & Noise [dB] & \multicolumn{1}{c|}{ Description of probability } \\
\hline Rare & 1 & $<\mathbf{8 0}$ & Risk occurrence is almost excluded \\
\hline Unlike & 2 & $\mathbf{8 0 - 8 5}$ & Risk occurrence is unlikely, but possible \\
\hline Possible & 3 & $\mathbf{8 5 - 8 7}$ & Risk occurrence is probable (occurs irregularly) \\
\hline Likely & 4 & $\mathbf{8 7 - 9 5}$ & Risk occurrence is very probable \\
\hline Almost certain & 5 & $\mathbf{> 9 5}$ & The danger of risk occurrence is highly probable \\
\hline
\end{tabular}

Tab. 5: Severity of impact of a risk event

\begin{tabular}{|c|c|l|}
\hline Consequence level & Value & \multicolumn{1}{|c|}{ Description of severity / consequence to hearing } \\
\hline Insignificant & $\mathbf{1}$ & $\begin{array}{l}\text { Slight harm and complaints such as unpleasant feelings, mild difficulties for conversation, fatigue and } \\
\text { psychological stress. }\end{array}$ \\
\hline Minor & $\mathbf{2}$ & $\begin{array}{l}\text { Moderate harm such as those mentioned above + Minor effect on human hearing, slight damage and } \\
\text { difficulties, such as discomfort, mild concentration difficulties, changes in blood pressure and in heart rate, } \\
\text { fatigue, mental stress. }\end{array}$ \\
\hline Moderate & $\mathbf{3}$ & $\begin{array}{l}\text { Fatigue, tiredness, headache and dizziness /temporary impairment of the hearing / mental stress / difficulty } \\
\text { with concentration and breathing / muscle pain / tinnitus / slight communication problems, etc. }\end{array}$ \\
\hline Major & $\mathbf{4}$ & $\begin{array}{l}\text { Severe hearing loss, extreme tingling and cramping of the upper extremities, serious communication } \\
\text { problems, severe sleeping disturbances etc. }\end{array}$ \\
\hline Catastrophic & $\mathbf{5}$ & $\begin{array}{l}\text { Catastrophic consequences, excessive increase in the risk of hearing damage and occurrence of occupational } \\
\text { disease. This noise level should be avoided in any case. }\end{array}$ \\
\hline
\end{tabular}

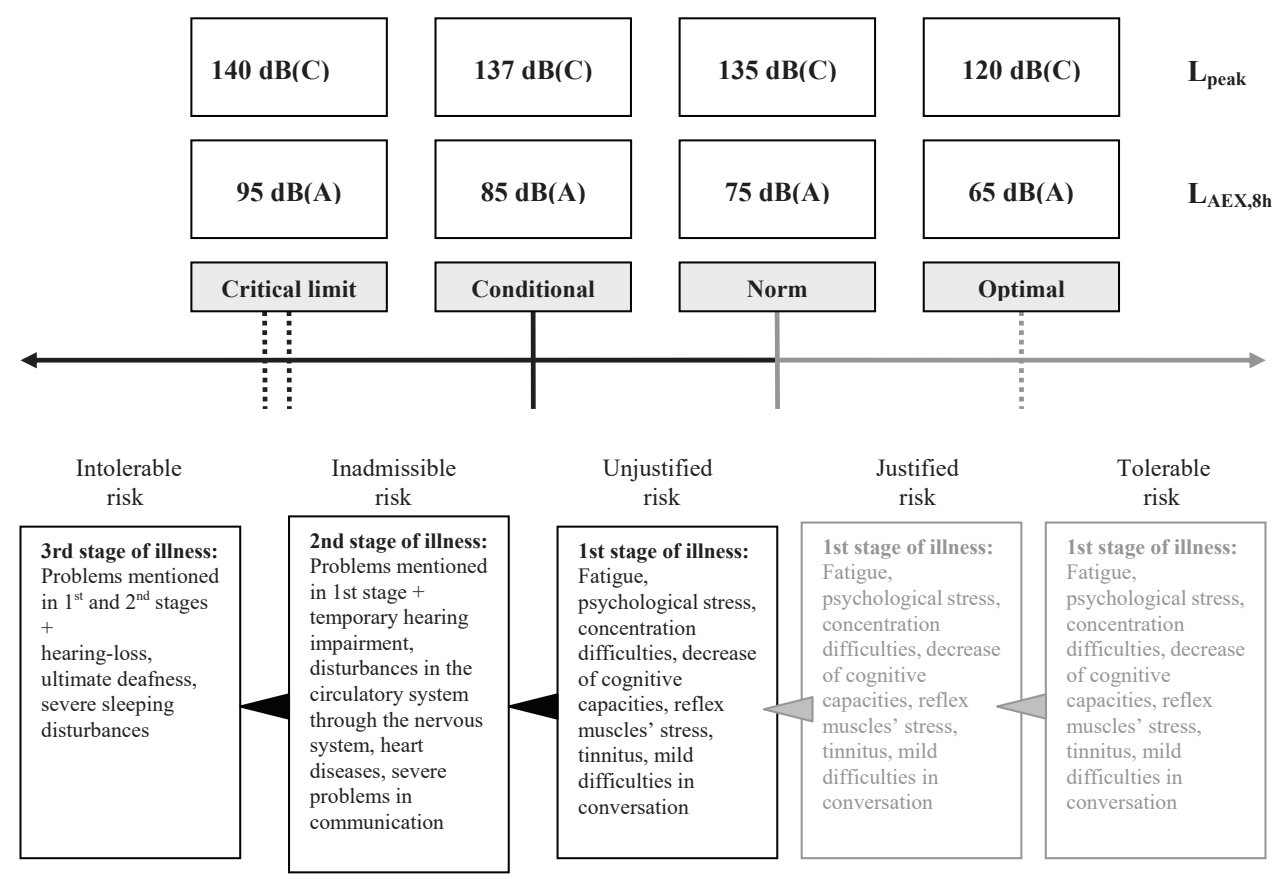

Fig. 1: Noise and risk criteria.

in an area of high to extreme risk severity. The average severity level of health risk assessment and of hearing impairment of the employees working in this workshop is 16, which represents a high, undesirable risk. By contrast, almost all employees of the workshop "Welding Center" work in an area with moderate risk level (the average severity level of risk is 8). In both cases it is necessary to implement measures aimed at risk reduction.

For comprehensive assessment and evaluation of the impact of noise on hearing and health of employees, we can use in the next step, in addition 


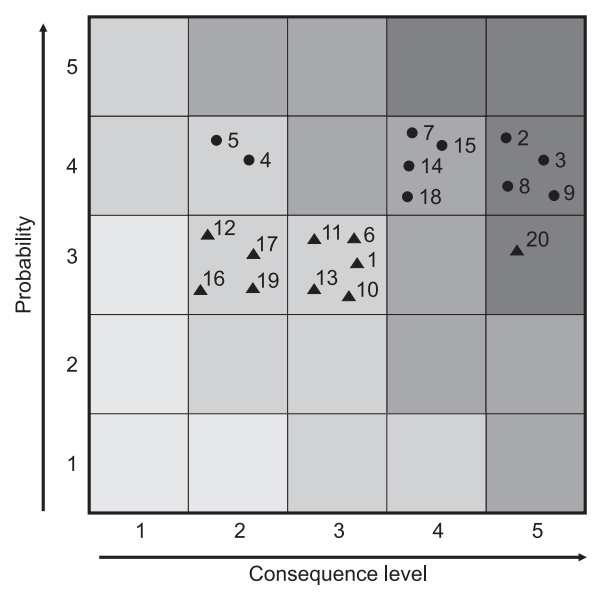

Fig. 2: Risk matrix.

to the probability $P$ of risk occurrence and the consequence of impact $C$, also the exposure time $E$. The exposure time $E$ takes into account the duration (time of exposure) of the conditions, during which the risk event affects a person and his hearing (Table 6).

Tab. 6: Exposure time -the time of duration of conditions for the hearing impairment risk.

\begin{tabular}{|l|l|l|}
\hline \multicolumn{1}{|c|}{ Exposure Level } & Value & Time [year] \\
\hline Negligible exposure time & 1 & $0-5$ \\
\hline Significant exposure time & 2 & $5-10$ \\
\hline High exposure time & 3 & $10-15$ \\
\hline Very high exposure time & 4 & $15-20$ \\
\hline Excessive exposure time & 5 & $>20$ \\
\hline
\end{tabular}

As distinct from the classical definition of risk, the risk in the case of the expanded definition is a function of three parameters, $R=f(P, C, E)$ and the resulting value is expressed as the product of

$$
R=P x C x E
$$

where $P$ is the probability of risk occurrence, $C$ is the severity of the risk, and $E$ is the exposure time.

Tab. 7: Severity level of a risk event.
In the case of a five-point scale of all parameters, the lowest achieved value of risk is 1 and the highest 125. As an unacceptable risk are often regarded values in the range from 70 to 125 (Tab.7).

For evaluation of the degree of risk and for assessment of mutual relations of the probability of risk occurrence $P$, of the effects on human health and hearing $C$ and of the exposure time $E$, we can use a spatial (cubic) diagram (Figure 3 ).

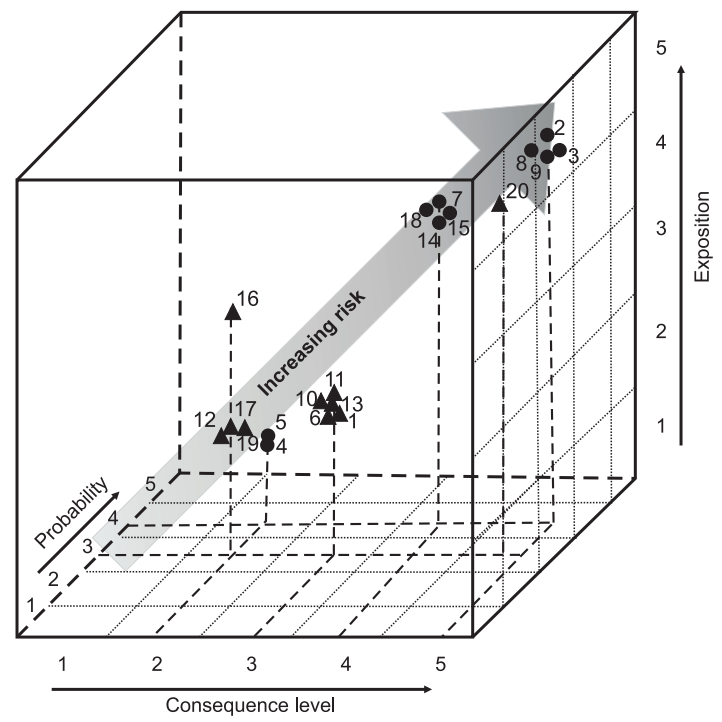

Fig. 3: Cubic matrix of risk.

The results of the analysis show that nine employees from both centers work in areas of unacceptable risk (over 75). The overall average level of severity of the risk of impact on health and hearing impairment of employees, also from the point of view of long-term exposure in the workshop "Welding Center" is 28, which is regarded as an acceptable risk. In the workshop "Cutting Center" the resulting value is as high as 76 . In this case, the working environment is dangerous and there is a risk of serious undesirable hearing impairment there.

\begin{tabular}{|c|c|l|}
\hline Risk level & Value & \multicolumn{1}{c|}{ Effect of risk } \\
\hline Insignificant, negligible risk & $\mathbf{1 - 4}$ & $\begin{array}{l}\text { The risk has negligible impact on human health and hearing; taking of corrective actions is not } \\
\text { required. }\end{array}$ \\
\hline Moderate risk & $\mathbf{5 - 1 0}$ & Severity of the risk is acceptable and no special measures are required. \\
\hline Tolerated risk & $\mathbf{1 1 - 5 0}$ & The risk is still acceptable, but it is necessary to take measures to reduce it. \\
\hline Serious, undesirable risk & $\mathbf{5 1 - 1 0 0}$ & $\begin{array}{l}\text { The environment is dangerous, there exist a risk of severe hearing impairment, it is necessary to } \\
\text { implement very soon measures for reducing the risk. }\end{array}$ \\
\hline Unacceptable risk & $\mathbf{1 0 1 - 1 2 5}$ & $\begin{array}{l}\text { The risk is unacceptable, persisting threat of permanent hearing impairment; the activity must be } \\
\text { suspended until elimination of the risk. }\end{array}$ \\
\hline
\end{tabular}




\section{Conclusions}

Evaluation of the quality of the working environment is of great importance for creating optimal conditions ensuring the comfort of man in the working environment.

When assessing noise in the work environment, it is of primary importance to determine the type of operation in it, the types of machines and of equipment used at work, the way of addressing issues of prevention of noise pollution, the technical condition of the machines and of the equipment used at work and so on.

In our opinion, noise as such cannot actually be exactly defined, because the same noise affecting different types of people causes different results, according to the circumstances. Long-term exposure of the human organism to noise pollution can cause, in addition to hearing impairment, a wide range of other diseases. Very high levels of noise cause hearing impairment, lower levels affect the control system in our body.

Reducing noise exposure in general is one of the important tasks of modern society. Noise issues are of global importance and measures for reducing and controlling noise are globally indispensable. These measures must be based on proper scientific evaluation of available data on the effects of noise, especially in relations between dose and response. The basis for this evaluation is the process of risk assessment and of risk management.

This paper deals with a proposal of assessment of hearing impairment risk from the point of view of long-term exposure to noise in a selected plant with engineering production. The measured results show that the normalized levels of noise exposure, extended by the uncertainty of measurement at the aforementioned workplaces, exceed the limits stipulated by the Slovak Government Decree № 115/2006 Coll. of Laws, and it is evident that according to the Ordinance № 448/2007 Coll. of Laws, all measured professions fall within the fourth category of work activities categorized according to the noise factor.

This paper presents the results of a study aimed at assessing the risks associated with acoustic noise in connection with exposure to noise at the workplace and with its possible negative effects (a risk event) to health and hearing of workers in the engineering industry. The main sources of noise in the plant under consideration were the technological units of a "Cutting Center" (workshop) and of a "Welding Center" (workshop) and the work activities of the employees at the neighboring workplaces.

The basis of assessment of working conditions with a possible relationship to diseases and injuries to health is the assessment of potential risk factors, i.e. of their level of interaction, by observation, by analysis of job description and of work procedures, by discussing the circumstances and the manner of performance of work activities, by measuring pollutants, loading and reactions of the organism, as well as by comparing the findings with the rules, limits and recommended values. It is also essential to take into account the measure of possible tolerance and the dynamics of the state of health of workers.

This paper can be regarded as a pilot study, which might be taken in the future as a basis for deeper analyses of some of the indicated issues. Its aim was to examine the impact of noise exposure on human health in a selected group of employees. The objects of the research were employees who were exposed to unfavorable working environment in selected production facilities during working hours. The research sample consisted of 20 male workers who are exposed to high levels of noise during their work on a long-time basis. As the negative effects of long-term exposure are revealed with a time delay, sometimes even of several years, we have decided to focus our attention in this study precisely on the assessment of risk of hearing impairment under conditions of longterm exposure to noise in working environment. We believe that this approach will help to get a clear and integrated approach to risk assessment during a long-term exposure of employees to noise during their work activity.

It should be noted that this issue is complicated and consequently there are many approaches to solving it. The methodology presented in this paper describes the view of the authors of the options for resolving this issue. The results presented in the paper are based on experience gathered up to now in the course of evaluation of environmental factors, effectively conducted by the authors.

\section{Acknowledgments}

This paper was written in frame of the work on the projects KEGA 032TUKE-4/2018 (50\%). The Slovak Research and 
Development Agency supported this work under the contract No. APVV-0432-12 (50\%).

\section{References and Notes}

[1] Maue J. Noise. Institute for Occupational Safety and Health of the German Social Accident Insurance (IFA), Germany. https://oshwiki.eu/wiki/Noise\#_ednref2.

[2] Berger $\mathrm{H}$. Active noise reduction (ANR) in hearing protection: Does it make sense for industrial applications? Paper presented at the 27th Conference of the National Hearing Conservation Association, Dallas. http://www.aearo.com/ pdf/hearingcons/anr.pdf.

[3] Šolc $\boldsymbol{M}$. Noise in the Occupational Environment as one of Important Factors Affecting Human Quality of Life. KIM, HF Technická univerzita v Košiciach, 7(1):85-91.

[4] Xiangdong Z. et al. Development of a noise metric for assessment of exposure risk to complex noise. Journal Acoustical Society of America. 126(2):703-712.

[5] Alberti PW. Noise and the ear. Scott-Browns Otolaryngology. Adult Audiology. (2):594-642.

[6] NOIS. Criteria for a recommended standard - Occupational noise exposure. DHHS NIOSH Publication.

[7] Prince MM. et al. Comments on a re-examination of risk estimates for the NIOSH Occupational Noise and Hearing Survey. Journal Acoustical Society of America. 103(5):27362739.

[8] Ahroon WA. et al. Complex noise exposures: an energy analysis. Journal Acoustical Society of America. 93(2):997-1006.

[9] NATO Research Study Group RSG6/PANEL8. The effects of impulse noise. NATO. 1110 Brussels. 33 p.

[10] Blakeslee EA. et al. Interaction of spectrally mismatched continuous and impulse-noise exposures in the chinchilla. Journal Acoustical Society of America. 61(S1).

[11] Hamernik RP. et al. The interaction between continuous and impulse noise: Frequency effects. Second International Conference on the Combined Effects of Environmental Factors, Koyei, Kanazawa, Japan.

[12] Buffet M.-A. - EUROGIP, France and Priha E. Tyoterveyslaitos Institutet for Arbetshygien - (FIOH), Finland. Workforce diversity and risk assessment: ensuring everyone is covered. European Agency for Safety and Health at Work. DOl: 10.2802/11532. ISBN 978-92-9191-267-4.

[13] Piňosová M. et al. Analysis of clinical signs of noise exposure of human health in plants with high exposure to noise. Annals of Faculty Engineering Hunedoara: international journal of engineering. 1(11):117-120.

[14] Ševčiková L. Hygiene - Environmental Medicine. Comenius University Publisher, editor. Bratislava; 2011. 330 p.

[15] Dianat l. et al. Association between objective and subjective assessments of environmental ergonomic factors in manu- facturing plants. International Journal of Industrial Ergonomics. 54(2016):26-31.

[16] Gavhed D. et al. Observed physical working conditions in a sample of call centres in Sweden and their relations to directives, recommendations and operators' comfort and symptoms. International Journal of Industrial Ergonomics. 37(2007):790-800.

[17] Seňová A. et al. Evaluation of risk by point method for selected carrer in mining industry. Acta Montanistica Slovaca. 13(2):278-84.

[18] Hnilica R. Synergy effect of risk factors in working environment and methods their assessment. Acta Facultatis Technicae. 17(2):25-34.

[19] Hrušková M. et al. Sledovanie a hodnotenie zdravotného stavu zamestnancov vo vybraných prevádzkach automobilového priemyslu. Pracovní lékařství. 67(3-4):86-91.

[20] Hnilica R. et al. Use of the analytic hierarchy process for complex assessment of the work environment. Quality and Quantity.51(1):93-101.

[21] Kapustová M. Aplikácia matematických metód pri ekologizácii pracovného prostredia $v$ strojárskych prevádzkach. Materials Science and Technology. (2):1-5.

[22] Tolvanen $K$. Exposure to bioaerosols and noise at a Finnish dry waste treatment plant. Waste Management and Research. 22(5):346-57.

[23] Provozník K. et al. Manuál prevence v lékařské praxi. VIII. Základy hodnocení zdravotních rizik. Praha.

[24] Passchier-Vermeer, W. et al. Noise Exposure and Public Health, Environmental Health Prespectives, 1(108):123-131.

[25] Piňosová, M. et al. Analýza klinických príznakov synergie pôsobenia hluku a vibrácií na zdravie človeka v prevádzkach s ich vysokou expozíciou. Pracovní lékařství. 64(2-3):103-111.

[26] Reinhold K. Protection of Workers against Noise at Industrial Workplace. International Conference on Electronics, Information and Communication Engineering Lecture Notes in Information Technology. (11):202-207.

[27] Directive 2003/10/EC on the minimum health and safety requirements regarding the exposure of workers to the risks arising from physical agents (noise). Official Journal of the European Union.

[28] Acoustics - Estimation of noise-induced hearing loss (Standard No. ISO 1999:2013). Geneva. Switzerland.

[29] Acoustics - Determination of occupational noise exposure - Engineering method. (Standard No. ISO 9612:2009). Geneva. Switzerland

[30] ŘíhaJ. Hodnocení investic na životní prostředí. Vícekriteriální analýza a ElA. Academia Praha.

[31] Plura, J. Plánováni a neustále zlepšování jakosti. Praha: Computer Press. 245 p. 